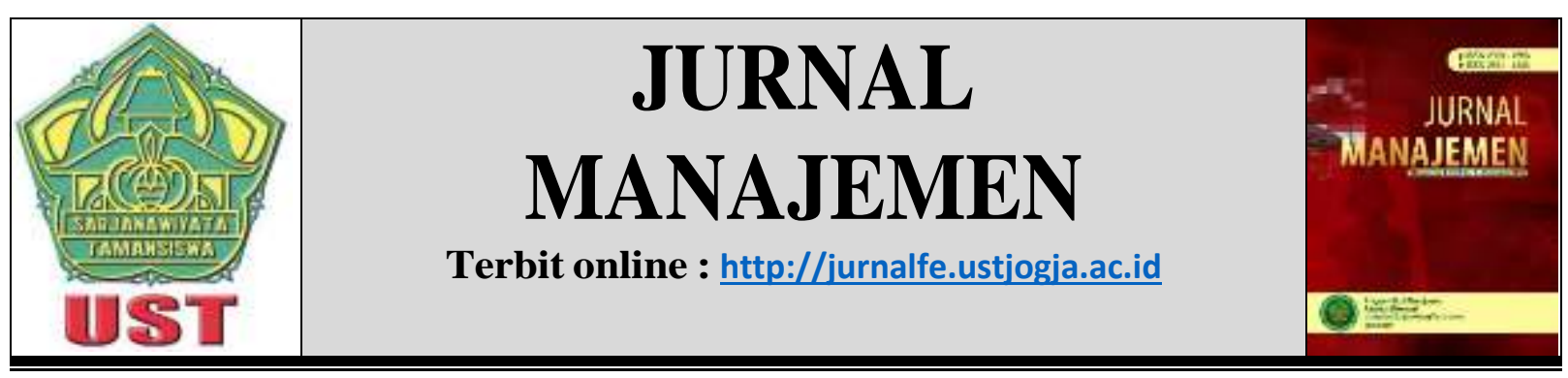

\title{
DETERMINASI HARGA-HARGA SAHAM BERDASARKAN FUNDAMENTAL FAKTOR STUDI KASUS PADA JAKARTA ISLAMIC INDEX TAHUN 2014 - 2018
}

\author{
Arnanda Ajisaputra \\ Program Studi Manajemen Sekolah Tinggi Ilmu Indocakti Malang \\ Email: paranggaruda@gmail.com
}

\begin{tabular}{|c|c|}
\hline Informasi Naskah & Abstrak \\
\hline Diterima: 9 November & This study aims to determine the effect of stock price movements on \\
\hline 2020 & EPS, PBV, and DER on shares indexed by JII during 2014 s.d. 2018. \\
\hline Revisi: 20 Februari 2021 & The research method uses the Quantitative Multiple Linear \\
\hline Terbit: 18 Juni 2021 & Regression Model. To take a sample from the population used \\
\hline Kata Kunci: EPS, PBV, & purposive sampling method. The results obtained were 15 issuers \\
\hline & indexed by JII continuously during 2015 s.d. 2018. Of the fifteen \\
\hline & issuers, they have EPS, PBV, and DER which simultaneously affect \\
\hline & their stocks price movements by $87.4 \%$, while $12.6 \%$ is influenced \\
\hline & by other factors. Partially, EPS has a significant and positive effect \\
\hline & on stock prices, $P B V$ also has a significant and positive effect on \\
\hline & $\begin{array}{l}\text { stock prices, but DER has a significant and negative effect on stock } \\
\text { prices. }\end{array}$ \\
\hline
\end{tabular}

\section{PENDAHULUAN}

Jakarta Islamic Index (JII) merupakan indeks saham yang mengindeks 30 emiten saham berkategori Syariah dengan kualifikasi tertentu. Kualifikasinya ditinjau dari tiga sisi yaitu: (1) berkategori syariah; (2) kekuatan fundamental; dan (3) kekuatan teknikal. Kualifikasi berkategori syariah maksudnya adalah mengharuskan emiten yang diindeks memiliki kriteria usaha yang halal secara syariah. Kualifikasi kekuatan fundamental dilihat dari dua sisi, yaitu: (1) total hutang yang berbasis bunga (non pembiayaan) dibandingkan dengan ekuitas tidak lebih dari 82\% dan (2) total pendapatan yang tidak diakui syariah lainnya dibandingkan dengan total pendapatan tidak lebih dari 10\%. Sedangkan kekuatan Teknikal dilihat dari adanya kapitalisasi pasar yang cukup besar dan pergerakan yang liquid (Tim Indonesia Stock Exchange, 2010).

Berdasarkan kriteria penilaiannya, indeks JII dipercaya menjadi rujukan para investor untuk menentukan saham yang bagus untuk investasi. Investor selalu melihat rasio-rasio keuangan untuk melihat kewajaran harga saham yang terbentuk (Raghu, 2010). Investor akan bergairah apabila harga saham yang dijual secara wajar di pasar, sebaliknya apabila harga yang terbentuk di pasar tidak wajar investor akan menarik sahamanya.

Beberapa faktor yang disorot investor dalam menganalisis fundamental perusahaan adalah tingkat 
laba suatu perusahaan, Earning per Share (EPS), Price to Book Value (PBV), Dept to Equity Ratio (DER) dan Deviden Payout Ratio (DPR). Dari kelima faktor fundamental tersebut ada tiga yang dinilai cukup kuat dalam mempengaruhi harga saham perusahaan yaitu EPS, PBV dan DER (Wira, 2014). Perusahaan yang menawarkan EPS lebih besar, akan disenangi oleh investor karena mengharap adanya pembagian Deviden yang besar pula. Semakin kecil PBV investor semakin bergairah, sebab harga saham menjadi semakin murah sehingga stimulus untuk membeli saham semakin meningkat. Sedangkan hukum berkebalikan terjadi pada DER, semakin besar DER membuat investor semakin khawatir akan kehidupan perusahaan tersebut, sebab tingginya DER menunjukkan pula tingginya tingkat rasio hutang perusahaan terhadap ekuitasnya (Andrew, 2013).

EPS, PBV dan DER memang ditampilkan dalam laporan keuangan perusahaan, hanya saja para investor akan mengalami kesulitan apabila harus menganalisis satu per satu ratusan emiten saham yang listing di Bursa Efek Indonesia (BEI). Untuk memudahkan menganalisis saham secara tepat, investor merujuk kepada sebuah indeks saham terlebih dahulu. Dimana indeks berfungsi menampilkan sahamsaham yang memiliki kriteria sesuai dengan syarat indeks tersebut, sebagaimana JII yang memiliki tiga syarat utama termasuk syarat emiten yang syar'i yang menjadi kuncinya (Wulandari, \& Sasongko, 2006).

Walaupun 30 emiten yang diindeks oleh JII dapat dikatakan layak, namun investor perlu menganalisis lebih mendalam terhadap faktor-faktor fundamentalnya sebelum memutuskan membeli sebuah emiten agar diketahui mana emiten yang memiliki prospek paling baik kedepannya. Salah satu upaya dalam menilai kelayakan investasi, perlu dipertimbangkan besar/kecilnya EPS, PBV, dan DER karena ketiganya mempengaruhi kewajaran harga yang terbentuk di pasar dan mempengaruhi trend pergerakan harganya.

Penelitian-penelitian terdahulu telah menyebutkan bahwa EPS, PBV dan DER mempengaruhi terbentuknya harga saham, namun demikian sample penelitian tersebut tidak merujuk kepada indeks melainkan merujuk kepada pengelompokan jenis industri. Sebagaimana penelitian Dewi \& Suaryana (2013) yang menghasilkan sebuah kesimpulan bahwa EPS, PBV, dan DER memiliki pengaruh signifikan terhadap harga saham berjenis Food and Beverage dengan sample sejumlah 15 emiten.

Penelitian lainnya juga menyatakan bahwa EPS, PBV, dan DER mempengaruhi terbentuknya harga namun ketiganya tidak dipadukan. Sebagaimana penelitian Dewi \& Suaryana (2013), yang memadukan antara EPS, ROA, ROE dan Harga Saham, dimana disimpulkan bahwa EPS, ROA, dan ROE berpengaruh signifikan terhadap harga saham. Penelitian Murniati (2016) membahas tentang efek dari Debt to Asset Ratio (DAR), Debt to Equity Ratio (DER), Return on Assets (ROA), Return on Equity (ROE), dan Net Profit Margin (NPM) terhadap harga saham, menghasilkan kesimpulan bahwa DER memiliki pengaruh yang signifikan dan positif terhadap harga saham.

Inti dari penelitian terdahulu menyatakan bahwa EPS, PBV, dan DER berpengaruh terhadap harga saham. Penelitian terdahulu menggambarkan bahwa EPS dan PBV berpengaruh signifikan positif terhadap harga saham, sedangkan DER berpengaruh signifikan negatif atau berkebalikan dengan harga saham sesuai dengan teori yang dikemukakan oleh Andrew (2013). Pengaruh dari faktor-faktor fundamental tersebut berdasarkan kategori atau jenis saham yang diteliti, bukan berdasarkan indeks.

Mengingat bahwa Jakarta Islamic Indeks (JII) merupakan indeks yang banyak dilirik oleh para investor sebelum memulai membeli saham untuk instrumen investasi mereka, perlu adanya penelitan yang menaliti tentang pengaruh faktor-faktor fundamental khususnya EPS, PBV, dan DER guna memberikan informasi aktual kepada calon investor sebelum menginvestasikan dana kepada emitenemiten terindeks JII. Apabila calon investor hanya melihat pergerakan harga saham dan menganilisisnya dengan analisis teknikal saja, akan berdampak pada informasi parsial yang dapat membuat panic efec. Panic efec adalah bentuk kepanikan pada investor (terlebih investor pemula) saat menghadapi situasi yang berbeda dari yang diprediksi sebelumya (Krantz, 2016).

Pergerakan harga saham JII pada tahun 2014 s.d 2018 cukup menggairahkan secara teknikal, bahkan indeks yang pernah dicapai selama lima tahun tersebut mampu mencapai angka 792 yang belum 
pernah menyentuh angka indeks tersebut sebelumnya (id.investing, 2019). Pergerakan harga saham pada indeks yang bergairah, belum tentu memunculkan kondisi fundamental yang baik, walaupun dalam jangka pendek hingga menengah terlihat aman. Determinasi faktor-faktor fundamental khususnya EPS, PBV, dan DER pada saham-saham terindeks JII perlu dianalisis lebih mendalam guna mengetahui apakah kondisi fundamental pada emiten-emiten saham terindeks JII tersebut memang benar-benar layak dijadikan instrumen investasi.

Berdasarkan urgensitas investor dalam mengetahui determinasi faktor-faktor fundamental (EPS, PBV, dan DER) emiten saham yang terindeks JII khususnya yang bergerak pada tahun 2014 s.d. 2018, maka dirasa perlu untuk meneliti, menganalisis, dan mempublikasikan hasilnya sebagai informasi, evaluasi, refleksi di masa mendatang serta bahan pertimbangan bagi investor yang akan menginvestasikan dananya kepada emiten-emiten saham terindeks JII. Oleh sebab itu, dalam jurnal penelitian ini diberikan judul "Determinasi Harga-Harga Saham Berdasarkan Fundamental Faktor Studi Kasus Pada Jakarta Islamic Index Tahun 2014 - 2018."

\section{KAJIAN PUSTAKA DAN HIPOTESIS Harga Saham}

Secara umum harga saham berarti nilai arus kas saat ini yang akan diterima oleh pemilik saham di kemudian hari (Coulling, 2017). Sedangkan menurut (Anoraga \& Puji (2001), harga saham merupakan nominal yang harus dikeluarkan oleh investor untuk membeli surat bukti penyertaan modalnya terhadap suatu perusahaan.

Harga saham terbentuk secara fluktuatif karena adanya permintaan dan penawaran di pasar bursa. Livermore (2015) seorang pakar analisis teknikal mengatakan "supply and demand rule stock prices in the short term" sehingga dapat difahami bahwa harga saham tidak bertahan lama dan dapat berubahubah dengan cepat seiring terbentuknya keseimbangan antara permintaan dan penawaran yang terjadi di pasar.

Persepsi berbeda dikemukakan oleh ahli fundamental, Raghu (2010) menyatakan bahwa harga saham terbentuk karena adanya profit yang dihasilkan oleh kinerja perusahaan. Tatkala sebuah perusahaan menghasilkan profit yang tinggi dan membagikan deviden dengan harga tinggi kepada investornya berpengaruh terhadap kenaikan harga saham perusahaan tersebut (Carolina, 2018).

Pernyataan Livermore (2015) yang berbasis teknikal dengan Raghu (2010) yang berbasis fundamental tidaklah bertentangan, keduanya hanya berbeda persepsi pandang tentang faktor-faktor yang mempengaruhi terbentuknya harga saham. Sebagaimana Mitropoulos, et.al (2015) menyatakan bahwa harga saham secara umum terbentuk karena dua faktor utama, yaitu faktor eksternal pasar yang melibatkan kemampuan perusahaan dan faktor internal pasar yang terbentuk karena permintaan dan penawaran.

\section{Jakarta Islamic Index (JII)}

JII merupakan sebuah indikator kinerja saham yang berbasis syariah dengan kriteria-kriteria yang ditentukan, terdiri atas 30 emiten saham yang tercatat di Bursa Efek Indonesia (BEI) dan dievaluasi setiap enam bulan sekali. Evaluasi tersebut berdasarkan kriteria yang ditetapkan oleh Bapeppam-LK dan DSNMUI terhadap seluruh emiten yang terindeks BEI.

Tahapan proses penyaringan emiten JII menurut Bursa Efek Indonesia (2019) adalah: (1) Saham Syariah yang masuk dalam konstituen Indeks Saham Syariah (ISSI) telah tercatat selama enam bulan terakhir; (2) dipilih 60 saham berdasarkan urutan rata-rata kapitalisasi pasar tertinggi selama satu tahun terakhir; (3) dari 60 saham tersebut, kemudian dipilih 30 saham berdasarkan nilai transaksi harian di pasar reguler tertinggi; (4) 30 saham yang tersisa merupakan saham terpilih. Kriteria nomor satu yang mengharuskan JII menilai berdasarkan saham-saham ISSI yang tercatat enam bulan terakhir merupakan aturan terbaru dari Otoritas Jasa Keuangan (OJK), mengingat ISSI baru dibentuk pada tanggal 12 Mei 
2011 sedangkan JII telah terbentuk pada tanggal 3 Juli 2000 (Bursa Efek Indonesia, 2019).

Embrio JII berasal dari saham syariah yang diterbitkan oleh PT Dana Reksa pada tahun 1997, berdasarkan Undang-undang Pasar Modal No 8 Tahun 1995 (Nasution \& Huda, 2007). Didasarkan atas undang-undang tersebut, pada tanggal 3 Juli 2000 PT Dana Reksa bekerjasama dengan PT Bursa Efek Jakarta (BEJ) yang kini telah berganti nama menjadi Bursa Efek Indonesia/BEI) membentuk sebuah indeks berbasis Syariah Islam bernama JII. JII merupakan indeks berbasis syariah yang menyaring 30 saham blue chip dan terdaftar di BEJ (Nasution \& Huda, 2007).

Menurut (Nasution \& Huda, 2007) syarat emiten diindeks oleh JII adalah: (1) memiliki jenis usaha berbasis Syariah atau tidak melanggar Syariah dan sudah berjalan selama tiga bulan dan terdaftar di BEI; (2) emiten harus memiliki saham yang rasio kewajiban terhadap aktiva $90 \%$ ke atas yang didasarkan atas laporan keuangan tengah atau akhir tahun; (3) dilihat sejumlah 60 emiten dengan rata-rata kapitalisasi pasar dan diambil 30 emiten dengan urutan likuiditas rata-rata berdsarkan nilai pasar reguler yang bergerak selama minimal satu tahun; (4) perusahaan tidak bergerak di dalam bidang yang mengandung unsur riba, maisir, dan gharar, serta memproduksi barang atau jasa yang halal.

\section{Faktor-faktor Fundamental}

Faktor-faktor fundamental merupakan nilai instrinsik sebuah saham dan rasio-rasio dari analisis fundamental. Nilai intrinsik sendiri adalah nilai riil berdasarkan resiko serta pengembalian yang dapat dipercaya, sedangkan rasio merupakan perbandingan nilai intrinsik dengan harga pasar yang muncul (Damodaran, 2011). Rasio sangat penting digunakan dalam analisis fundamental guna mengetahui apakah harga saham yang terbentuk di pasar sesuai dengan kewajaran ataukah tidak. Rasio juga dapat digunakan untuk memprediksi dan menarik garis trend secara fundamental terhadap kondisi perusahaan di masa yang akan datang berbasis kondisi perusahaan di masa sekarang.

Banyak rasio yang digunakan oleh para investor dalam menganalisis harga saham yang terbentuk, namun hanya beberapa saja yang seringkali digunakan para investor terkait efektifitas dan keakuratan hasilnya. Sebagaimana disampaikan oleh Raghu (2010) bahwa dari sekian banyak rasio keuangan yang digunakan untuk menganalisis harga saham, Earning per Share (EPS); Price Earning Ratio (PER); Debt to Equity Ratio (DER); Price to Book Value (PBV); Return on Equity (ROE); dan Return on Assets (ROA) yang seringkali dijadikan alat analisis funamental oleh para investor karena efektifitas dan keakuratan hasilnya dalam menganalisis harga saham, melihat kondisi keuangan perusahaan, meramalkan kondisi perusahaan, serta menganalisis pendapatan investasi (deviden) yang akan mereka dapatkan.

\section{Earning per Share (EPS)}

Dilihat dari sudut pandang investor, EPS merupakan sebuah rasio untuk mengukur laba bersih per lembar saham. Rasio ini membandingkan antara laba bersih sebuah perusahaan dengan saham yang beredar, sehingga dengan EPS investor dapat mengetahui hasil yang diterima dari investasinya apabila Pay Out Ratio sebesar 100\% (Graham, 2006). Sedangkan apabila dilihat dari sudut pandang pengelola modal, bahwa EPS merupakan laba bersih per unit dari suatu perusahaan yang dihitung selama satu periode tertentu (Siamat, 2004).

Semakin tinggi nilai EPS maka semakin besar deviden yang akan diterima oleh investor (Darmadji \& Fakhrudin, 2001). Tingginya nilai EPS juga berdampak pada peningkatan jumlah investor yang membeli saham perusahaan tersebut (Pasaribu, 2008). (Wulandari \& Sasongko, 2006) menyatakan di dalam penelitiannya bahwa EPS berdampak pada harga dan peningkatan volume pembelian terhadap saham perusahaan yang diteliti.

Consler, et.al (2011) meneliti lebih lanjut pengaruh antara besarnya EPS dengan Deviden yang dibagi serta volume pembelian atas deviden yang berubah tersebut. Hasilnya sebagaimana Pasaribu (2008) serta Wulandari, \& Sasongko (2006) bahwa EPS berpengaruh positif terahadap Deviden dan 
Deviden berpengaruh positif pula terhadap besarnya jumlah volume pembelian sebuah saham di suatu perusahaan yang ditelitinya. Penelitian lebih lugas tentang pengaruh EPS terhadap Harga Saham salah satunya telah dilakukan oleh Dewi \& Suaryana (2013) yang menghasilkan kesimpulan bahwa EPS berpengaruh secara signifikan dan positif terhadap Harga Saham. Dalam arti bahwa semakin tinggi nilai EPS, maka semakin tinggi pula Harga Saham yang terbentuk demikian sebaliknya.

\section{Price to Book Value (PBV)}

PBV merupakan sebuah nilai dengan fungsi mengetahui apakah harga pada saham suatu emiten tergolong murah atau mahal. Secara teknis PBV merupakan nilai rasio yang memberikan petunjuk kepada investor terhadap perbandingan antara harga saham dengan nilai buku saham tersebut (Athanasius, 2012).

PBV dapat memberikan gambaran terhadap potensi perubahan harga saham secara tidak langsung dengan membagi antara market value dengan book value suatu perusahaan. Tatkala market value dibandingkan dengan book value akan dapat memberikan gambaran kepada investor berapa kali market value suatu saham dihargai dari book value nya, sehingga inilah fungsi utama PBV terhadap analisis fundamental sebuah perusahaan (Jensen, et.al, 1997).

Semakin tinggi nilai PBV terhadap mayoritas saham yang bergerak di sektor yang sama, maka nilai wajar atas market value perusahaan tersebut semakin rendah (Dimitrios, 2011). Dalam penelitian Dewi \& Suaryana (2013) PBV memiliki pengaruh signifikan terhadap pergerakan harga saham secara positif. Semakin nilai PBV tinggi, maka harga saham semakin meningkat secara signifikan.

\section{Dept to Equity Ratio (DER)}

DER merupakan salah satu rasio solvabilitas yang dapat menggambarkan besaran hutang terhadap modal perusahaan. Kartini \& Arianto (2008) mengatakan bahwa DER memiliki fungsi untuk mengukur tingkat penggunaan hutang perusahaan terhadap total shareholder's equity nya. Rasio tingkat hutang perusahaan terhadap modalnya berfungsi sebagai rambu-rambu perusahaan dalam membentuk struktur modalnya.

Darsono \& Ashari (2010) mengemukakan bahwa DER merupakan salah satu rasio solvabilitas yang berfungsi sebagai rambu-rambu perusahaan dalam mengukur kemampuannya untuk membayar kewajiban tatkala perusahaan tersebut dilikuidasi. DER juga memberikan petunjuk kepada perusahaan dalam mengetahui kemampuan perusahaan untuk melunasi jutang jangka panjangnya, informasi ini tidak saja diperlukan oleh perusahaan namun juga oleh investor sebagai bahan pertimbangan investasi mereka (Kat, 2001). Menurut Darsono \& Ashari (2010) rasio ini sangat penting dalam trading on equity karena dapat memberikan gambaran terhadap investor, sehingga aksi investor tersebut memberikan dampak positif dan negatif terhadap rentabilitas modal perusahaan.

DER diukur berdasarkan perbandingan antara total hutang dengan total ekuitas dengan rumusan

DER $=\frac{\text { Total Hutang }}{\text { Total Ekuitas }}$ (Horne \& Wachowicz, 2009). Dari rumusan tersebut dapat diketahui faktor-faktor pembentuk DER yaitu hutang, baik hutang lancar maupun hutang jangka panjang dan modal serta pengaruhnya terhadap harga saham.

Dari penelitian Dewi \& Suaryana (2013) diketahui bahwa hubungan antara DER dengan harga saham perusahaan berjenis Food and Beverage adalah signifikan, namun memiliki timbal balik yang negatif. Artinya, bertambah nilai DER harga saham justru akan semakin merosot. Penelitian ini berbeda dengan penelitian yang dilakukan oleh Samsuar (2017) yang menghasilkan keputusan bahwa DER mempengaruhi Harga Saham secara signifikan namun berkorelasi positif, sehingga semakin besar nilai DER semakin meningkat pula harga saham. 


\section{Hipotesis Penelitian}

Sesuai dengan teori dan penelitian terdahulu yang disampaikan, hipotesis penelitian ini menduga bahwa:

1. Secara Simultan, variabel $X_{1}, X_{2}$, dan $X_{3}$ berpengaruh terhadap Harga Saham Terindeks JII

2. Variabel $X_{1}$ (EPS) secara parsial berpengaruh terhadap Harga Saham Terindeks JII

3. Variabel $\mathrm{X}_{2}$ (PBV) secara parsial berpengaruh terhadap Harga Saham Terindeks JII

4. Variabel $X_{3}$ (DER) secara parsial berpengaruh terhadap Harga Saham Terindeks JII

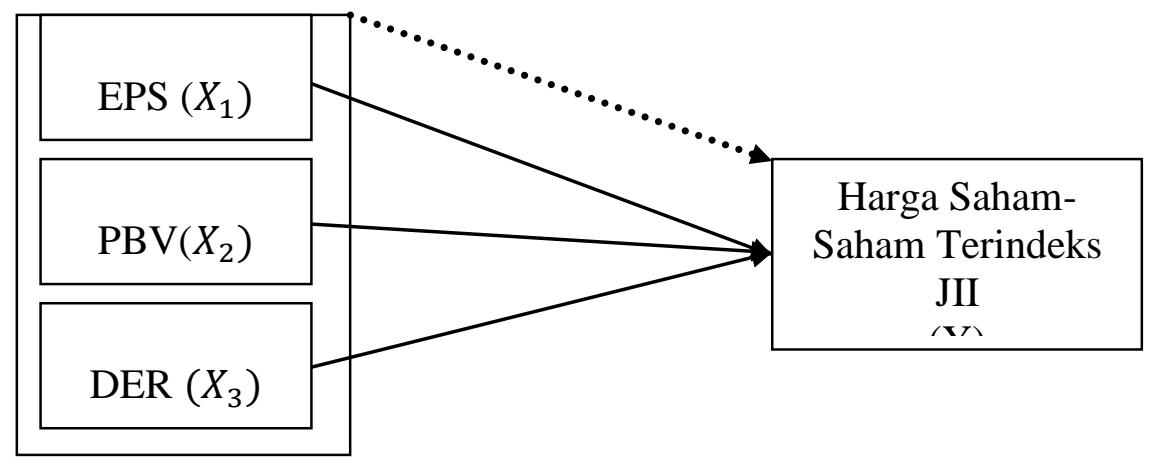

Sumber: Peneliti, 2019

Bagan 1. Kerangka Pikir Penelitian

Keterangan:

$\longrightarrow \quad$ : Garis Hubungan Parsial

…...... : Garis Hubungan Simultan

\section{METODE PENELITIAN}

Populasi dan Sampel

Populasi penelitian ini adalah seluruh saham yang listing di Bursa Efek Indonesia (BEI). Adapun sampelnya menggunakan nonprobabilitas sampling, yaitu teknik pengambilan sampel dengan tidak memberikan kesempatan yang sama pada anggota populasi (Larson, 2017).

Menurut Larson (2017) dalam penelitian Sosial dan Ekonomi sering digunakan metode nonprobabilitas sampling karena memiliki beberapa pertimbangan tertentu. Penelitian ini membuat sampel berdasarkan pertimbangan bahwa emiten yang diuji adalah emiten yang terindeks JII dan tidak dikeluarkan dari JII selama lima tahun yaitu mulai dari tahun 2014 sebagai patokan emiten terdaftar hingga tahun 2018.

Berdasarkan pertimbangan penarikan sampel di atas, maka sampel dapat dikategorikan sebagai Purposive Sampling yang mengarah kepada Quota Sampling. Purposive sampling adalah penarikan sampel berdasarkan pertimbangan-pertimbangan yang cocok atas target dalam populasi. Adapun Quota Sampling adalah penentuan kecocokan atas Purposive Sampling didasarkan atas kuota maksimal yang sebanding dengan komposisi masing-masing kelompok (Cochran, 2010).

\section{Definisi Variabel}

Variabel yang digunakan dalam penelitian ini adalah Variabel Y dan Variabel X: (1) Variabel Y adalah harga saham-saham yang terindeks JII selama lima tahun yaitu antara tahun 2014 s.d 2018. Adapun harga yang dipilih adalah closing price, yaitu harga penutupan akhir tahun; (2) Variabel X, merupakan variabel faktor-faktor yang diteliti pengaruhnya terhadap harga saham. Variabel X merupakan variabel bebas, yaitu variabel yang tidak terikat namun diduga dapat mempengaruhi variabel Y dalam hipotesis (Brandimarte, 2011)

Dalam penelitian ini variabel $\mathrm{X}$ terdiri atas tiga komponen yaitu: (a) $X_{1}$ : Earning per Share (EPS). 
Nilai EPS tidak dapat langsung diketahui melalui data mentah, melainkan harus diolah terlebih dahulu menggunakan rumus EPS $=\frac{\text { Laba Bersih Setelah Pajak }}{\text { Jumlah Saham Beredar }}$ dengan satuan yang menyertainya adalah mata uang, dalam penelitian ini adalah Rupiah (Graham, 2006); (b) $X_{2}$ : Price Book Value (PBV). Nilai PBV tidak dapat langsung diketahui melalui data mentahnya, namun juga harus diketahui nilai bukunya dan harga sahamnya. (Jensen, et.al, 1997) membagi langkah perhitungan PBV dengan tiga tahap yaitu: mencari nilai buku, menentukan harga saham, dan menghitung PBV perusahaan dengan rumus $P B V=$ $\frac{\text { Harga Saham }}{\text { Book Value }}$ (c) $X_{3}$ : Debt Equity Ratio (DER). Dalam laporan keuangan perusahaan secara teknis telah diketahui tentang total hutang dan total ekuitasnya, sehingga dalam penelitian ini tidak diperlukan rumus turunannya. DER $=\frac{\text { Total Hutang }}{\text { Total Ekuitas }} \times 100 \%$, satuan yang menyertainya adalah persen.

\section{Teknik Analisis Data}

Analisis data dalam penelitian ini menggunakan analisis deskriptif kuantitatif yaitu analisis yang menguji hubungan antar variabel serta menampilkan ringkasan dari gambaran data yang diperoleh (Brandimarte, 2011). Adapun model penelitian ini menggunakan regresi berganda, yaitu penelitian regresi linear dengan lebih dari satu variabel bebas dengan persamaan:

$$
\mathrm{Y}=\alpha+\beta_{1} X_{1}+\beta_{2} X_{2}+\beta_{3} X_{3}+\mathrm{e}
$$

Dimana:

Y = Harga saham-saham terindeks JII

$\alpha \quad=$ Konstanta

$\beta_{1}$ s.d $\beta_{5}=$ Koefisien determinasi

$\mathrm{X}_{1} \quad=$ Earning per Share (EPS)

$\mathrm{X}_{2} \quad=$ Price Book Value (PBV)

$\mathrm{X}_{3} \quad=$ Debt Equity Ratio (DER)

e $\quad=$ Error Term, faktor-faktor di luar penelitian (Basuki \& Prawoto, 2016)

Sebelum melakukan uji hipotesis dilakukan uji asumsi klasik yaitu: (1) Uji Normalitas berfungsi untuk memastikan data penelitian terdistribusi normal ataukah tidak dengan mengguakan metode KSmirnov yang dibantu oleh program IBM SPSS Statistic Versi 25; (2) Uji Heteroskedastisitas berfungsi untuk menguji terjadinya perbedaan varian terhadap nilai-nilai residual pada setiap periode pengambilan data yang satu dengan periode pengambilan data yang lainnya (Sunyoto, 2012). Uji Heteroskedastisitas dalam Penelitian ini menggunakan Uji Glejser, menurut Sugiyono (2016) Uji Glejser tepat digunakan dengan sample besar ( $>30)$; (3) Uji Multikollinearitas adalah sebuah uji asumsi klasik untuk mengetahui apakah di dalam sebuah model regresi terdapat hubungan yang sangat kuat terjadi antar variabel bebas (Sunyoto, 2012). Menurut Sugiyono (2016) dasar pengambilan keputusan Miltikollinearitas dapat dilakukan dengan dasar Nilai Tolerance dan Nilai VIF; (4) Uji Autokorelasi merupakan uji asumsi klasik yang data-datanya terpengaruh oleh waktu, dalam penelitian ini data-data pada variabel bebas yang diambil terkait dengan perubahan waktu, oleh sebab itu peneliti merasa perlu untuk melakukan uji Autokorelasi (Sunyoto, 2012). Dalam mengetahui apakah adanya autokorelasi diperlukan sebuah interpretasi dari pengolahan data, dalam penelitian ini menggunakan Durbin Watson (D-W). Alasan peneliti menggunakan Uji D-W karena variabel terikat dalam model penelitian bukanlah variabel Lag. Apabila data yang diuji sebesar dU < d < (4-dU), maka untuk memastikan diperlukan Uji Run Test dengan dasar pengambilan keputusan menurut Martono (2010), yaitu: Apabila Asymp.Sig.(2tailed) < 0,05, terdapat gejala autokorelasi dan Apabila Asymp.Sig.(2-tailed) >0,05, tidak terdapat autokorelasi.

Uji hipotesis yang dilakukan adalah dengan menggunakan Uji F untuk menguji hipotesis 1 yang menyatakan hipotesa adanya pengaruh simultan faktor-faktor fundamental terhadap harga saham-saham yang terindeks JII selama lima tahun yang telah disebutkan dan menggunakan Uji $\mathrm{t}$ untuk menguji hipotesis 2,3, dan 4 yang menyatakan hipotesa adanya pengaruh parsial faktor-faktor fundamental 
terhaap harga saham-saham yang terindeks JII selama lima tahun yang telah disebutkan.

\section{HASIL DAN PEMBAHASAN}

Perbedaan mendasar dari penelitian ini dengan penelitian terdahulu baik yang disampaikan oleh Pasaribu (2008), Wulandari \& Sasongko (2006), Consler, et.al (2011), maupun Kartini \& Arianto (2008) adalah pengambilan sampel penelitian dari emiten yang diambil. Apabila penelitian terdahulu yang diresume mengambil sampel pada tiap jenis kategori industri, maka penelitian ini mengambil sampel emiten dari Jakarta Islamic Indeks (JII) yang bertahan selama lima tahun, dari tahun 2014 s.d 2018.

Dari banyak emiten yang terindeks JII selama lima tahun, didapatkan 15 emiten yang terus menerus diindeks JII tanpa sekalipun dikeluarkan. Emiten-emiten tersebut adalah: ADRO, AKRA, ASII, BSDE, ICBP, INDF, INTP, KLBF, PGAS, SMGR, SMRA, TLKM, UNTR, UNVR, dan WIKA.

\begin{tabular}{lrrrrr}
\multicolumn{7}{c}{ Tabel 1. Statistik Deskriptif } \\
\hline N & \multicolumn{1}{c}{ Minimum } & \multicolumn{1}{c}{ Maximum } & \multicolumn{1}{c}{ Mean } & \multicolumn{1}{c}{ Std. Deviation } \\
\hline Harga Saham & 72 & 515.00 & $45,400.00$ & $7,961.5417$ & $8,981.92868$ \\
EPS & 72 & 27.19 & $2,432.04$ & 412.9092 & 467.77851 \\
PBV & 72 & .36 & 53.59 & 3.8649 & 7.96414 \\
DER & 72 & .15 & 2.70 & .8954 & .55762 \\
Valid N (listwise) & 72 & & & & \\
\hline
\end{tabular}

Sumber: IBM SPSS Statistic Ver 25, 2019

Berdasarkan tabel Statistik Deskriptif tidak terdapat nilai negatif di minimumnya, khususnya pada EPS dan DER. Pada EPS tidak terdapat nilai negatif karena emiten terindeks JII selama 2014 s.d. 2018 selalu mendapatkan laba yang dibagi sebagai deviden. Sedangkan DER tidak terdapat nilai negatif di minimumnya karena emiten yang terindeks JII selama 2014 s.d. 2018 memiliki jumlah modal yang lebih besar daripada hutangnya.

Hasil Uji Normalitas dengan metode K-Smirnov diketahui bahwa Asymp. Sig. (2-tailed) > 0,05 yaitu senilai 0,063, sehingga data terdistribusi normal. Hasil Uji Heteroskedastisitas dengan metode Uji Glejser, didapatkan data Variabel $\mathrm{X}_{1}(\mathrm{EPS}), \mathrm{X}_{2}(\mathrm{PBV})$, dan $\mathrm{X}_{3}$ (DER), seluruhnya bernilai lebih besar daripada 0,05 , sehingga dari data tersebut dapat disimpulkan bahwa tidak terjadi gejala Heteroskedastisitas. Hasil Uji Multikollinearitas berdasarkan nilai Tolerance dan VIF diketahui bahwa $\mathrm{X}_{1}$ (EPS), $\mathrm{X}_{2}(\mathrm{PBV})$, dan $\mathrm{X}_{3}$ (DER) lebih besar dari 0,10, sedangkan berdasarkan nilai VIF dari $\mathrm{X}_{1}$ (EPS), $\mathrm{X}_{2}$ (PBV), dan $\mathrm{X}_{3}$ (DER) lebih kecil daripada 10,00, dari informasi tersebut dapat disimpulkan bahwa tidak terjadi multikollinearitas pada model regresi dalam penelitian. Berdasarkan Uji Autokorelasi Uji Durbin-Watson, nilai uji D-W adalah 1,561 (dL) $<1,594<1,675$ (dU), sehingga belum dapat disimpulkan. Guna memperjelas kesimpulan ada atau tidaknya autokorelasi digunakan Uji Run Test dengan hasil nilai Asypm. Sig. (2-tailed) 0,812>0,05, sehingga dapat disimpulkan tidak terdapat gejala autokorelasi.

Dari hasil analisis Regresi Linier Berganda dapat disusun persamaan linier sebagai berikut:

$\mathrm{Y}=1351,527+14,009 \mathrm{X}_{1}+518,245 \mathrm{X}_{2}+(-1315,394) \mathrm{X}_{3}+\mathrm{e}$

Variabel Y adalah variabel dependen yaitu harga saham. Konstanta $(\alpha)$ sebesar 1351,527 yaitu apabila EPS, PBV, dan DER dianggap nol, maka harga saham sebesar Rp 1.351,53. Variabel $\mathrm{X}_{1}$ (EPS) sebesar 14,009 yaitu apabila variabel lain tetap dan EPS mengalami peningkatan sebesar $1 \%$ akan meningkatkan harga saham sebesar Rp 14,01. Variabel $\mathrm{X}_{2}$ (PBV) sebesar 518,345, yaitu apabila PBV meningkat 1\% sementara variabel lain tidak mengalami perubahan akan meningkatkan harga saham sebesar Rp 518,35. Variabel $\mathrm{X}_{3}$ (DER) tatkala mengalami peningkatan sebesar $1 \%$ dengan tidak adanya perubahan pada variabel lainnya akan menurunkan harga saham sebesar Rp 1.315,40. 
Tabel 8. Koefisien Determinasi

\begin{tabular}{|c|c|c|c|c|}
\hline Model & $\mathrm{R}$ & R Square & Adjusted R Square & Std. Error of the Estimate \\
\hline 1 &, $935^{\mathrm{a}}$ & ,874 & 868 & , 16651 \\
\hline
\end{tabular}

Sumber: IBM SPSS Statistic Ver 25, 2019

Dari data di atas R Square bernilai 0,874, artinya 87,4\% Harga Saham ditentukan oleh EPS, PBV, dan DER sedangkan 12,6\% lainnya ditentukan oleh variabel di luar ketiganya.

\begin{tabular}{llrrrrr}
\multicolumn{7}{c}{ Tabel 9. Uji F } \\
ANOVA \\
Model & & Sum of Squares & df & Mean Square & F & \multicolumn{1}{c}{ Sig. } \\
\hline 1 & Regression & 13,029 & 3 & 4,343 & 156,631 &, $000^{\text {b }}$ \\
& Residual & 1,885 & 68 &, 028 & & \\
& Total & 14,914 & 71 & & & \\
\hline
\end{tabular}

Sumber: IBM SPSS Statistic Ver 25, 2019

Dari hasil uji ANOVA, diketahui bahwa Sig. < 0,05 dengan $F_{\text {hitung }}(156,63)>F_{\text {Tabel }}(2,74)$, sehingga $\mathrm{H}_{0}$ ditolak sedangkan $\mathrm{H}_{1}$ diterima. Dari uji simultan diketahui bahwa Harga Saham dipengaruhi secara bersama oleh EPS, PBV dan DER.

Tabel 10. Uji-T

Coefficients $^{\mathrm{a}}$

\begin{tabular}{llcrrrr}
\hline & \multicolumn{7}{c}{ Standardized } \\
Model & & \multicolumn{2}{c}{ Unstandardized Coefficients } & \multicolumn{2}{c}{ Coefficients } \\
Beta & \multicolumn{1}{c}{ t } & \multicolumn{1}{c}{ Sig. } \\
\hline 1 & (Constant) & 1,767 &, 194 & & 9,090 &, 000 \\
& EPS_Log &, 830 &, 044 &, 839 & 18,661 &, 000 \\
& PBV_Sqrt &, 123 &, 021 &, 254 & 5,711 &, 000 \\
& DER_Sqrt &,- 237 &, 107 &,- 100 & $-2,226$ &, 029 \\
\hline
\end{tabular}

Sumber: IBM SPSS Statistic Ver 25, 2019

Dari hasil Uji-T terhadap Hipotesis (H2, H3, H4,) didapatkan hasil sebagai berikut:

1. EPS berpengaruh signifikan positif terhadap Harga Saham. Dapat dilihat dari Sig. $<0,05$ dan $F_{\text {hitung }}$ $(18,661)>\mathrm{F}_{\text {tabel }}(1,995)$, sehingga $\mathrm{H}_{\mathrm{a}}$ diterima dan $\mathrm{H}_{\mathrm{o}}$ ditolak.

2. PBV berpengaruh signifikan positif terhadap Harga Saham. Dapat dilihat dari Sig. $<0,05$ dan $F_{h i t u n g}$ $(5,711)>\mathrm{F}_{\text {tabel }}(1,995)$, sehingga $\mathrm{H}_{\mathrm{a}}$ diterima dan $\mathrm{H}_{\mathrm{o}}$ ditolak.

3. DER berpengaruh signifikan negatif terhadap Harga Saham .Dapat dilihat dari Sig. $<0,05$ dan $F_{\text {hitung }}$ $(-2,226)>\mathrm{F}_{\text {Tabel }}(1,995)$, sehingga $\mathrm{H}_{\mathrm{a}}$ diterima dan $\mathrm{H}_{\mathrm{o}}$ ditolak.

\section{PEMBAHASAN}

Penelitian ini fokus menguji adanya pengaruh faktor-faktor fundamental yang mempengaruhi pergerakan harga saham tiap tahunnya. Faktor-faktor fundamental yang diuji dalam penelitian ini adalah Earning per Share (EPS), Price to Book Value (PBV), dan Deviden Payout Ratio (DER). Waktu uji penelitian diambil kurun waktu lima tahun mulai tahun 2014 s.d. 2018.

Perbedaan utama penelitian ini dengan penelitian yang lainnya terletak pada sample uji yang digunakan. Pada penelitian terdahulu sebagaimana penelitian Pasaribu (2008); Dewi \& Suaryana (2013); dan Samsuar (2017) mengambil sample faktor-faktor fundamental dan harga saham pada perusahaan- 
perusahaan yang serumpun, semisal perusahaan yang bergerak di bidang food and beverage, properti, dan perbankan. Penelitian ini menggunakan nonprobability sampling dengan metode purposive sampling berdasarkan indeks tertentu. Indeks yang ditentukan adalah Jakarta Islamic Indeks (JII) dengan alasan indeks ini mencangkup fungsi dan penggunaan pada investor dengan ragam yang luas.

Perusahaan yang dipilih adalah perusahaan yang selama lima tahun tidak pernah dikeluarkan kategori indeksnya oleh JII dan didapatkan 15 emiten yang layak untuk dilakukan pengujian, yaitu: ADRO, AKRA, ASII, BSDE, ICBP, INDF, INDF, INTP, KLBF, PGAS, SMGR, SMRA, TLKM, UNTR, UNVR, dan WIKA. Degan faktor fundamental yang ditentukan yaitu: Harga Saham untuk Variabel Dependen (Y); EPS untuk Variabel Independen $\left(\mathrm{X}_{1}\right)$; PBV untuk Variabel Independen $\left(\mathrm{X}_{2}\right)$; dan DER untuk variabel Independen $\left(\mathrm{X}_{3}\right)$.

persamaan Regresi Berganda $Y=1351,527+14,009 X_{1}+518,245 X_{2}+(-1315,394) X_{3}+$ e. Apabila tidak ada faktor-faktor yang mempengaruhi, Harga Saham dari kelima belas emiten tersebut senilai Rp 1.351,53. Apabila ditambah variabel independen dengan menafikkan variabel yang lainnya, harga saham akan bertambah senilai Rp 14,01 tatkala ada kenaikan satu poin dari EPS; harga saham juga akan bertambah senilai Rp 518,25 dengan bertambahnya satu point dari PBV; namun harga saham akan berkurang sejumlah Rp 1.315,40 dengan bertambahnya satu point DER.

EPS, PBV, dan DER adalah mayoritas faktor-faktor yang menentukan kelima belas harga saham yang terindeks JII selama tahun 2014 s.d 2018 dengan kekuatan pengaruh sebesar 87,4\%, sedangkan $12,6 \%$ lainnya dipengaruhi oleh faktor-faktor yang lainnya. Dalam Uji Simultan, telah diketahui bahwa hipotesis diterima, yang berarti EPS, PBV, dan DER memang mempengaruhi pergerakan harga saham dari kelima belas emiten terindeks JII selama tahun 2014 s.d. 2018.

Hasil penelitian ini sangat penting sebagai refleksi para calon investor dalam mempertimbangkan ketiga faktor fundamental tersebut. EPS, PBV, dan DER yang memiliki determinasi kuat terhadap pergerakan harga saham sangat perlu dipertimbangkan sebelum beralih kepada analisis teknikal. Mengandalkan analisis teknikal saja akan dapat membuat panic efec, tatkala momentum datang, sedangkan momentum bersifat jangka pendek sedangkan investor mengharapkan profit di masa depan, tentu yang dilihat adalah potensi pergerakan jangka panjang.

Di masa pandemik COVID-19 ini, para calon investor harus jeli melihat keadaan. Secara teknikal pergerakan saham tidak terkecuali JII dan emiten yang terindeks mengalami kemerosotan tajam, pasar bursa secara teknikal tidak bergairah, namun tidak demikian apabila para calon investor jeli menganalisis dan merefleksikan determinasi ketiga faktor terebut terhadap potensi pergerakan harga saham di masa depan. EPS, PBV, dan DER merupakan ketiga faktor yang cukup dalam analisa dasar melihat potensi dan peluang fundamental kedepan. Apabila determinasinya kuat, diharapkan lima tahun mendatang pergerakan JII dan emiten-emiten yang terindeks di dalamnya memiliki potensi pergerakan yang cukup bagus, sebaliknya apabila determinasinya lemah maka untuk sementara ditinggalkan dan beralih indeks lain sebagai acuan analisis lebih mendalam.

Penelitian ini telah membuktikan bahwa pergerakan emiten-emiten terindeks JII selama lima tahun dari 2014 s.d. 2018 memiliki determinasi cukup kuat, sehingga layak dipertimbangkan para calon investor untuk dianalisis lebih mendalam. Analisis yang diharapkan adalah determinasi per kategori sebagaimana penelitian sebelumnya, dan analisis teknikal.

\section{PENUTUP}

Ternyata EPS , PBV, dan DER tidak hanya mempengaruhi Harga Saham pada emiten yang terkumpul dalam satu kategori usahanya saja, namun juga mempengaruhi Harga Saham yang terkumpul dalam sebuah indeks, dalam hal ini adalah Jakarta Islamic Index (JII), sehingga apabila investor akan menganalisis dan membandingkan faktor-faktor fundamental hanya pada emiten Syariah yang tertuang pada indeks khususnya JII tidak menjadi suatu masalah.

Dari Uji Parsial dapat diketahui bahwa EPS berpengaruh positif terhadap Harga Saham kelima 
belas emiten terindeks JII selama tahun 2014 s.d 2019, begitupula dengan PBV, hanya saja untuk DER mempengaruhi Harga Saham kelima belas emiten tersebut seacara negatif. Dengan diterimanya keseluruhan hipotesis disimpukan bahwa pengaruh perubahan EPS, PBV dan DER terhadap harga saham tidak saja dalam satu kategori emiten saja, semisal emiten yang bergerak di bidang food and beverage saja atau yang bergerak di bidang properti saja, namun apabila emiten tersebut dikelompokkan ke dalam sebuah indeks tetap saja Harga Sahamnya dipengaruhi oleh perubahan EPS, PBV, dan DER.

Menilik latar belakang dalam penleitian ini, investor syariah yang akan menentukan pembelian saham syariah sebagai instrumen investasi tidak perlu melakukan ceklist satu per satu apakah saham-saham yang akan dibeli masuk kategori syariah atau tidak, namun cukup melihat emiten yang diindeks JII kemudian dianalisis kelayakan investasinya. Karena semua emiten yang diindeks JII adalah emiten berkategori Syariah dan aman dalam pandangan Syariah serta beberapa faktor-faktor fundamentalnya khususnya EPS, PBV, dan DER pasti mempengaruhi Harga Saham yang terbentuk sebagai salah satu pertimbangan investasi.

\section{REFERENSI}

Andrew, A. (2013). Stock Trading Money Management (Trend Following Mentor) (Kindle Edition). CreateSpace Independent Publishing Platform.

Anoraga, P \& Puji, P. (2001). Pengantar Pasar Modal (Edisi Revi). PT Adi Mahasatya.

Athanasius, T. (2012). Berinvestasi Saham. PT Elex Media Komputindo.

Basuki, A. T., \& Prawoto, N. (2016). Analisis Regresi dalam Penelitian Ekonomi dan Bisnis. Raja Grafindo Persada.

Brandimarte, P. (2011). Quantitative Methods: An Introduction for Business Management (1 ed). John Wiley \& Sons, Inc.

Bursa Efek Indonesia. (2019). PT Bursa Efek Indonesia. PT Bursa Efek Indonesia. http://www.idx.co.id Carolina, D. (2018). Analisis Penilaian Kewajaran Harga Saham dengan Menggunakan Pendekatan Funamental pada PT Panin Sekuritas, Tbk. Jurnal Media Wahana Ekonomika, 15(2), 22-34.

Cochran, W. G. (2010). Teknik Penarikan Sampel (3 ed). UI Press.

Consler, J., Greg, M. L., \& Susan, F. H. (2011). Earning per Share Versus Cash Flow per Share as Predictor of Dividends per Share. Managerial Finance, 37(5), 288-482.

Coulling, A. (2017). Stock Trading \& Investing Using Volume Price Analysis Over 200 Worked Examples of This Estraordinary Methodology. CreateSpace Independent Publishing Platform.

Damodaran, A. (2011). The Little Book of Valuation. John Wiley \& Sons, Inc.

Darmadji, T., \& Fakhrudin, M. (2001). Pasar Modal Indonesia, Pendekatan Tanya Jawab. Salemba Empat.

Darsono \& Ashari. (2010). Pedoman Praktis Memahami Laporan Keuangan. Andi.

Dewi, P. D. A., \& Suaryana, I. G. N. A. (2013). Pengaruh EPS, DER, dan PBV Terhadap Harga Saham. E-Jurnal Akuntansi Universitas Udayana, 4(1), 215-229.

Dimitrios, M. (2011). The impact of intellectual capital on firms' market value and financial performance. Journal of Intellectual Capital, 12(1), 132-151.

Graham, B. (2006). The Intelligent Investor (Revised Ed). HarperCollins Publishers.

Horne, J. C. van, \& Wachowicz, J. M. (2009). Fundamentals of Financial Management (13th ed). Prentice Hall.

id.investing. (2019). Jakarta Islamic, Indonesia. Id.Investing. https://id.investing.com/charts/stockscharts

Jensen, G. R., Johnson, R. R., \& Mercer, J. M. (1997). New Evidence on Size and Price-to-Book Effects in Stock Returns. Financial Analysts Journal, 53(6), 34-42.

Kartini, \& Arianto, T. (2008). Struktur Kepemilikan, Profitabilitas, Pertumbuhan Aktiva dan Ukuran Perusahaan terhadap Struktur Modal pada Perusahaan Manufaktur. Jurnal Keuangan Dan 
Perbankan, 12(1), 11-21.

Kat, M. H. (2001). Structured Equity Derivatives. The Definitive Guide to Exotic Option and Stuctured Notes. John Wiley \& Sons, Inc.

Krantz, M. (2016). Fundamental Analysis for Dummies (2nd ed.). John Wiley \& Sons, Inc.

Larson, N. G. (2017). The Sampling Method in Social and Economic Research: A Partial List of References. Forgotten Book.

Livermore, J. (2015). How to Trade in Stock-The Classic Formula for Understanding Timing, Money Management, and Emotional Control (Kindle Edition). Albion Press.

Mitropoulos, P., Talias, M. A., \& Mitropoulos, I. (2015). Combining stochastic DEA with Bayesian analysis to obtain statistical properties of the efficiency scores: An application to Greek public hospitals. European Journal of Operational Research, 243(1), 302-311.

Murniati, S. (2016). Effect of Capital Structure, Company Size and Profitability on the Stock Price of Food and Beverage Company Listed on the Indonesia Stock Exchange. Information Management and Business Review, 8(1), 23-29.

Nasution, M. E., \& Huda, N. (2007). Investasi pada Pasar Modal Syariah. Kencana.

Pasaribu, R. B. F. (2008). Pengaruh Variabel Fundamental Terhadap Harga Saham Perusahaan Go Public di BEI. Jurnal Ekonomi Dan Bisnis, 2(2), 101-113.

Raghu, P. (2010). Fundamental Analysis for Investors (4 ed). Vision Book Pvt. Ltd.

Samsuar, T., \& A. (2017). Pengaruh Faktor Fundamental dan Teknikal Terhadap Harga Saham Industri Perhotelan yang Terdaftar di Bursa Efek Indonesia. Jurnal Ekonomi, Keuangan, Dan Perbankan Syariah, 1(1), 116-131.

Siamat, D. (2004). Manajemen Lembaga Keuangan (4 ed). Fakultas Ekonomi Universitas Indonesia.

Sugiyono. (2016). Metode Penelitian Kuantitatif, Kualitatif, dan Kombinasi (Mixed Methods). Alfabeta. Sunyoto, D. (2012). Analisis Validitas dan Asumsi Klasik. Gava Media.

Tim Indonesia Stock Exchange. (2010). Buku Panduan Indeks Harga Saham Bursa Efek Indonesia. Indonesia Stock Exchange Builidng.

Wira, D. (2014). Analisis Fundamental Saham. Exceed.

Wulandari, \& Sasongko, N. (2006). Amrullah, A. 2010. Kariato: Indikator Andalan Pasar Global Saham, Indeks, Komoditi, dan Valas. Jakarta: Elex Media Komputindo. Andrew, A. 2013. Stock Trading Money Management (Trend Following Mentor) (Kindle Edition). Florida: CreateSpace Independent Publ. Empirika, 19(1), 64-80. 